\title{
Complainant Identity: Things to Consider in Obtaining Customers' Feedback in Public Transportation
}

\author{
Andrey S. Mikhaylov ${ }^{1} \&$ Anna A. Mikhaylova ${ }^{1}$ \\ ${ }^{1}$ Immanuel Kant Baltic Federal University, A.Nevskogo str. 14, 236041, Kaliningrad, Kaliningrad region, Russia \\ Correspondence: Andrey Mikhailov, Immanuel Kant Baltic Federal University, A.Nevskogo str. 14, 236041, \\ Kaliningrad, Kaliningrad region, Russia. Tel: 7-952-400-526. E-mail: mikhailov.andrey@yahoo.com
}

Received: October 10, 2014

Accepted: December 2, 2014 Online Published: February 25, 2015

doi:10.5539/res.v7n3p149

URL: http://dx.doi.org/10.5539/res.v7n3p149

\begin{abstract}
This article investigates the factors that act as barriers in obtaining customer complaints in public transportation services in the city of Kaliningrad, Russia. It seeks to understand what external and internal factors discourage dissatisfied customers from filing a complaint to the service company, and allocate regularities with regard to personal attributes of the individual groups of respondents. Data were collected from a survey held in May and June 2014 using a judgmental sampling method. Research results suggest that complainant's gender, age, and income level predetermine individual perceptions over the influence of factors that might stop a customer from filing a complaint. On average, depending on the type of problem, up to $90 \%$ of dissatisfied customers do not voice their complaints to the service provider.
\end{abstract}

Keywords: customer feedback, customer complaint behavior, service quality, public transportation

\section{Introduction}

Public transportation services has long been a highly competitive market, represented by the ever growing modes of transportation - buses, trams, trolleybuses, metro, etc. (Atalik, 2009; Duval, 2007). Yet, in recent years, urban transport companies have stumbled upon a fearsome competition on behalf of the substitute services, such as car and bicycle city rentals, car sharing, etc. The market offerings in the niche of public transportation services are being constantly refined. Customers, given the variety of choices, are easily enticed by the 'competitors' (i.e. substitute offerings), often encouraged by the society, in example, due to environmental issues (e.g. in case of bicycles or electric vehicles). Clearly, the are plenty of reasons to the possible outflow of passengers in favor of other means of transportation, thus management goal is to maintain excellent service quality and set a dialogue with the customers. Customer feedback is regarded as an inexhaustible source of information on the service performance, whereas customer complaint is the most valuable piece of knowledge. While the importance of obtaining customer complaints is left undoubtable, researchers are faced with the challenge of non-complainants.

\section{Theoretical Background}

\subsection{Barriers to Customer Complaint Behavior}

Customer complaint barriers are extensively studied by Best and Andreasen (1977), Blodgett et al. $(1995,1997)$, Dabholhar, (1994), Keaveney (1995), McCollough et al. (2000), Oliver and Swan (1989), Singh (1989, 1990), Smith et al. (1999), Stephens and Gwinner (1998), Tronvoll (2008) to name just a few. Generally, scholars consider three main group of factors that strongly affect customer's intention to file a complaint. These factors are costs and benefits associated with filing a complaint, contextual resources, and customer's personal competences. Various individual factors within these broad categories reflect the subjective evaluation of the gap between the cost and benefit of complaint, i.e. whether the complaint is worth the effort. Tronvoll (2008) describes them as situational factors that influence the final decision, being context sensitive and heterogeneous. Among other important parameters that influence customer's evaluation of the complaint reasonability, self-confidence and recovery expectations are the perceived service importance (e.g. see Bloch \& Richins, 1983; Blodgett et al., 1995; Day \& Ash, 1979), failure severity (e.g. see Dunning et al., 2004; Goodwin \& Ross, 1992; Hoffman et al., 1995; Smith et al., 1999), attribution of blame (e.g. see Krishnan \& Valle, 1979), zone of tolerance (e.g. Mikhaylov \& Mikhaylova, 2014) and a number of others. Hence, most of the conceptual developments on the topic of customer complaint behavior, including complaint barriers, focus on the matter of 
the service failure (i.e. the reason of complaint), leaving aside the individual differences of the complainant.

At the same time, scholars acknowledge the subjective nature of customer's evaluation of the service quality, and actions taken in case of the service failure. In fact, a multiplicity of factors influencing a complex phenomenon of customer complaint behavior and the determination to take the first step, include consumers' demographics and psychographics, individual attitude towards complaining, predominantly formed by the social standards, etc. Thereby, drawing on publications of Crosier and Erdogan (2001), Davidow and Dacin (1997), Day and Landon (1976; 1977), Bearden and Mason (1984), Richins (1982), we are eager to define personal attributes of a complainant that can be generalized and regarded as influential in evaluating the dependences of certain external and internal barrier-factors that discourage customers from filing a complaint to the service company.

\section{Methodology}

To examine individuals' attitude towards the factors of complaint barriers with regard to public transportation in Kaliningrad, a questionnaire survey approach on the data collection was adopted, which is the most widely used method to design research on customer complaint behavior (see, for example, Best and Andreasen, 1977; Day and Landon, 1976; Fellesson and Friman 2008). The questionnaire form is structured under five dimensions: 1) open-ended questions on the real incident experience; 2) ranking of the most irritating factors while using public transport; 3) ranking of the possible reaction in case of a negative critical incident; 4) ranking of the barrier-factors that are likely to discourage from filing a complaint; 5) personal information (gender, age, education, profession, income level, availability of a car or a bicycle, frequency of bus usage and experience from other cities / countries, the main reason for using public transport).

In order to ensure the sufficient sample size of the population, a formula of Anton (1996, p.89) was applied:

$$
\text { Sample Size }=2500 * N^{*}(1,96)^{\wedge} 2 /\left(25^{*}(N-1)+2500 *(1,96)^{\wedge} 2\right)
$$

Where:

$\mathrm{N}$ is total population (population of Kaliningrad is 433,5 thous.pers.).

1.96 is the standard deviation (Z-score).

Adherence to the formula provides a confidence interval of $95 \%$. A total number of 384 accurately filled questionnaires were used in the following analysis. A judgmental sampling method ensured the respondents are current users of the public transportation services and are as socially diverse as possible. The aim was to ensure the equal coverage of various social groups, in particular by age, gender and income level. Additionally, interviewers provided a full coverage of all popular urban bus routes of the city, route numbers $27,21,36,35,5$, $44,17,11,7,32$, and 28; listed in descending order.

\section{Research Results and Discussion}

The survey involved 384 residents of the city of Kaliningrad in age from 13 to 77 years, and a nearly equal distribution of men and women (due to the judgmental sampling method). Nearly $40 \%$ of respondents use the public transport every day and another $30.5 \%$ several times a week. Almost $42 \%$ of Kaliningradians have encountered problematic situations while using public transportation services over the last few years. However, the majority of citizens ( 45 to $86 \%$ depending on the type of problem) chose not to file a complaint to the service company.

To identify the underlying causes that keep passengers from filing a complaint, the respondents were asked to assess the degree of influence that different factors have on a scale from 1 to 7 , where 1 stands for "the least influential" and 7-the impact is "most influential". Then, based on these estimates, all of the factors were ranked by the strength and scale of their impact on the respondents (Figure 1). It was found that the strongest impact over the passengers' intention to engage in a complaint behavior has the time (a long period of receiving the response, the duration of the feeding process) and cost factors (the need to spend time, money), as well as lack of confidence in getting the desired result, the inability to eliminate the use of public transport, and unfriendly employees during the complaint process; factors are listed in descending order of importance.

The study suggests that the strength of the impact of these barrier factors varies depending on gender, age and income level of the respondents (see Figure 2 and 3). Barrier factors that predominantly keep women from filing complaints in comparison with men can be divided into three groups. The first group of factors associated with various types of expenses. The main factor- "the need to spend time and / or money". The influence of this factor on female respondents is $10.9 \%$ greater than on men. The second group of factors is related to the direct resolution of the problem. It includes factors that demonstrate lack of confidence in the fact that the problem will be resolved completely and timely, and that it will have a significant impact on the overall quality of services provided by public transport in future. Average cumulative impact of factors of the second group on the female 
respondents is by $6.9 \%$ greater than on men. Factors of the third group are of social nature. They are related to the personal qualities of the person and the employees' attitude towards the complaining customer. The proportion of women for whom personal diffidence or unfriendly attitude of the staff becomes an obstacle to the complaint is by $5.5 \%$ more than a similar proportion of men.

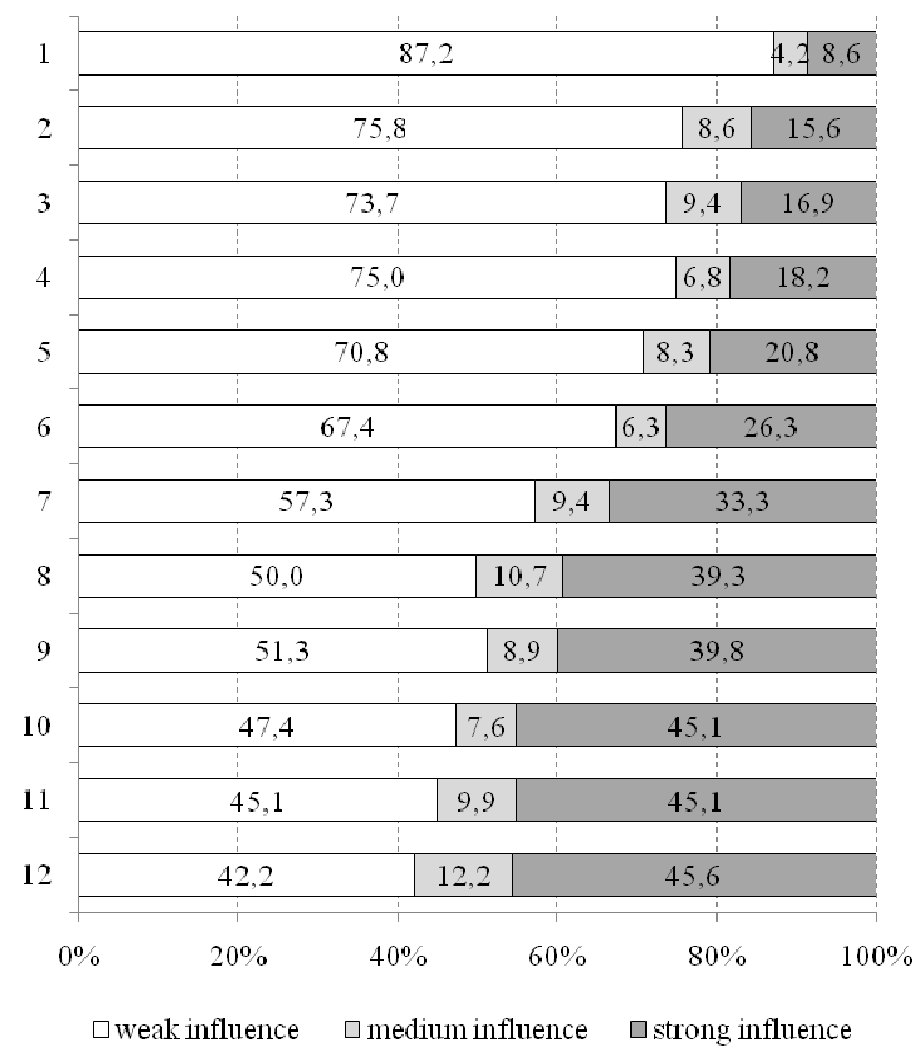

Figure 1. Overall distribution of barrier factors on making a complaint to the service company by the strength and scale of their impact on the respondents

Note. 1 - Technical difficulties (no phone, Internet, fax, etc. available); 2 - Personal beliefs (hesitate, taciturn); 3 Mentality (complaining is unacceptable in Russia); 4 - Language barrier (i.e. the driver does not speak Russian); 5 - Do not know what to do; 6 - No compensation provided; 7 - No possibility to abandon the use of public transport (busses); 8- Unfriendly (boorish) behavior of employees; 9 - Too bureaucratized complaint procedure; 10 - The need to spend personal time and / or money; 11 - High probability that the problem will not be resolved; 12 - Takes too long to get a response (exceeding the time of relevance) 


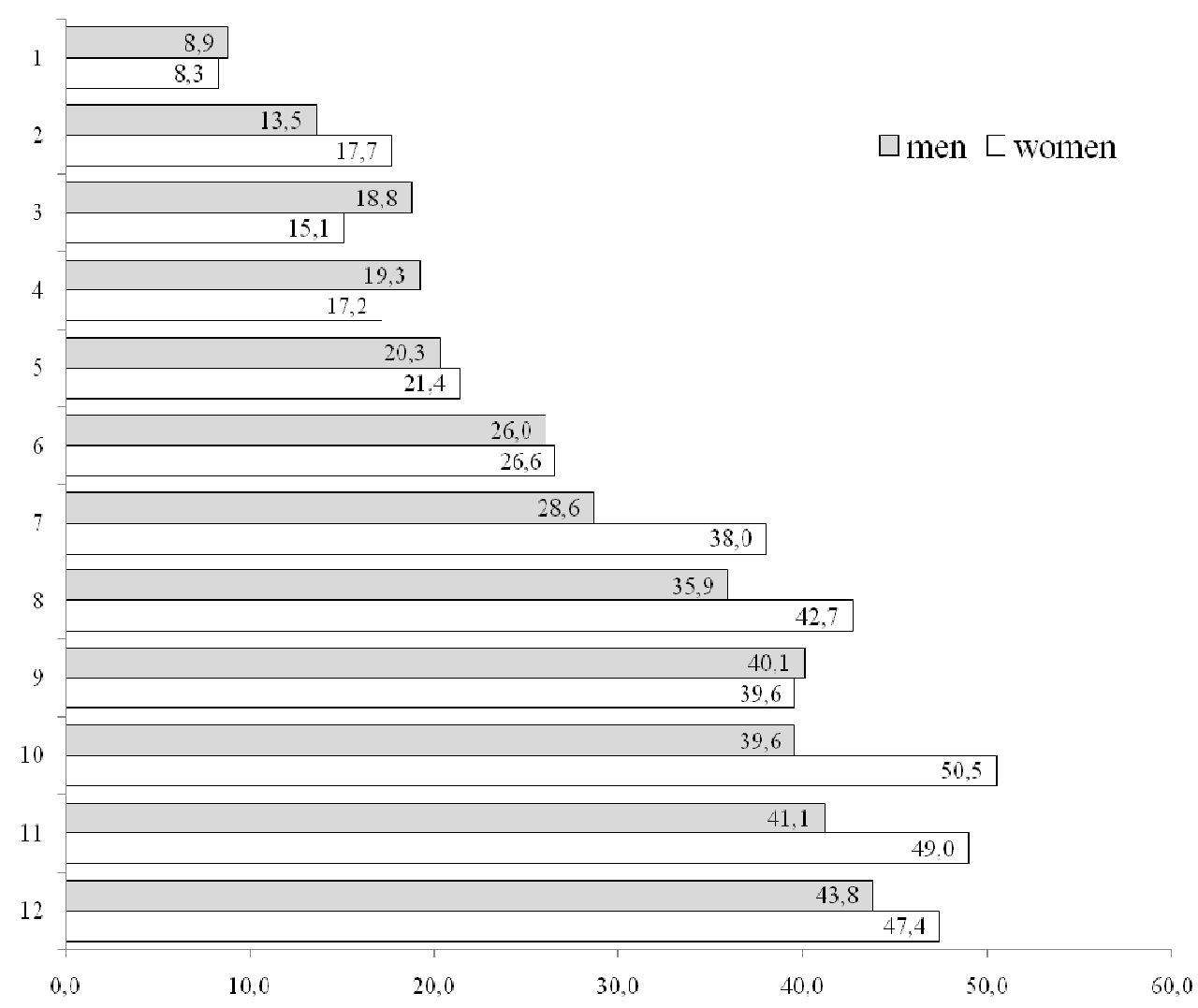

Figure 2. Distribution of factors acting as barriers to the complaint, by the respondents' gender

Note. 1 - Technical difficulties (no phone, Internet, fax, etc. available); 2 - Personal beliefs (hesitate, taciturn); 3 Mentality (complaining is unacceptable in Russia); 4 - Language barrier (i.e. the driver does not speak Russian); 5 - Do not know what to do; 6 - No compensation provided; 7 - No possibility to abandon the use of public transport (busses); 8- Unfriendly (boorish) behavior of employees; 9 - Too bureaucratized complaint procedure; 10 - The need to spend personal time and / or money; 11 - High probability that the problem will not be resolved; 12 - Takes too long to get a response (exceeding the time of relevance) 


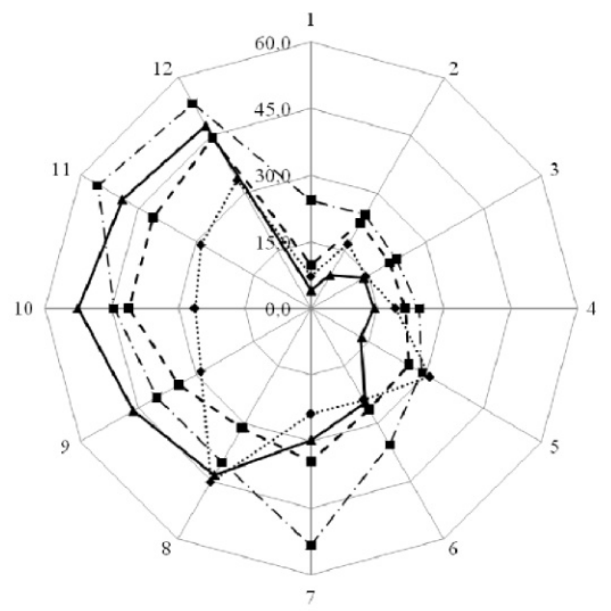

a) based on respondents' age

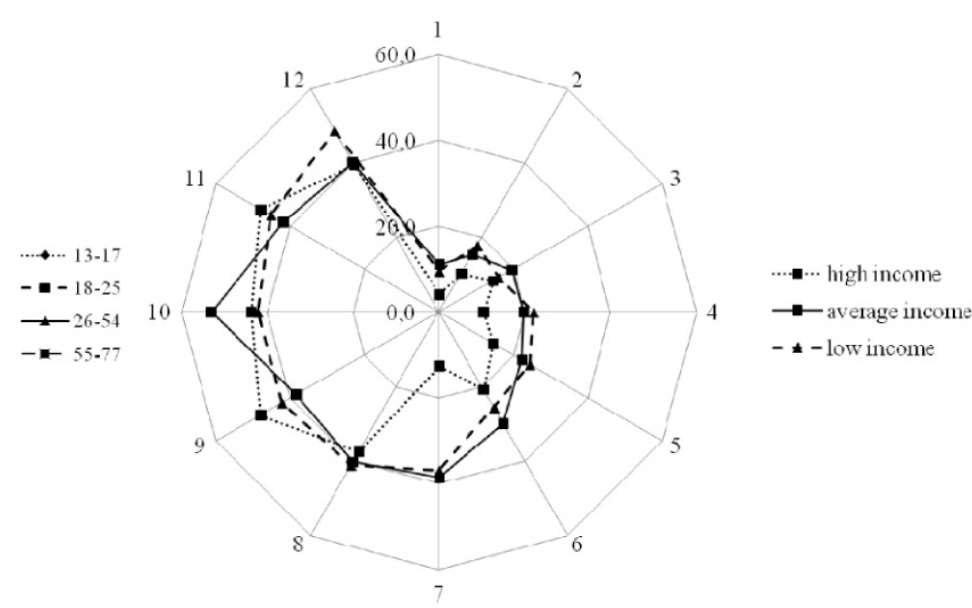

b) based on respondents' income level

Figure 3. Distribution of barrier factors to filing a complaint to the company

Note. 1 - Technical difficulties (no phone, Internet, fax, etc. available); 2 - Personal beliefs (hesitate, taciturn); 3 Mentality (complaining is unacceptable in Russia); 4 - Language barrier (i.e. the driver does not speak Russian); 5 - Do not know what to do; 6 - No compensation provided; 7 - No possibility to abandon the use of public transport (busses); 8- Unfriendly (boorish) behavior of employees; 9 - Too bureaucratized complaint procedure; 10 - The need to spend personal time and / or money; 11 - High probability that the problem will not be resolved; 12 - Takes too long to get a response (exceeding the time of relevance)

Age of the complainant also has a significant influence over the decision to file a complaint (Figure 2a). Current research suggests four age groups: under 17 years old- "underage"; from 18 to 25 years old- "young people" (mostly university students); from 26 to 54 years old-"working people"; over 55 years of age- "retired". Underage respondents are highly influenced by the employees' attitude. Almost half of the respondents in the group one will not file a complaint if they feel that the staff are set unfriendly. Another one-third believe that filing a complaint makes no sense, since the solution to the problem needs immediate attention, and will lose its relevance after some time, or they are simply unfamiliar with the complaint procedure. To a lesser degree of constraint are personal beliefs, especially the mentality and technical difficulties.

For the second age group the factor of time is of particular importance. About $40 \%$ of young people do not intend to spend their time, energy and money to make a complaint, since the problem might remain unresolved, or lose its relevance after some time. Almost 35\% respondents of the second group have no possibility to abandon public transport services, thus they are easy on the issues that arise. Moreover, the share of shy or ignorant customers, concerning the complaint procedure, is generally higher in this age group than the average.

The third age group are experienced people with a job and steady income, and, in some cases, car owners. The vast majority of these type of customers $(87 \%)$ are aware of the required complaint process. The mentality, personal beliefs and technical difficulties for almost $90 \%$ of the group representatives does not play a significant role in the decision to file a complaint. However, they are most sensitive to spent their time and money. For half of the respondents the factor "requires spending personal time and / or money" is the main obstacle to the complaint. About 50\% consider it inappropriate to complain, because the resolution is unlikely or it will most certainly lose its relevance by that time. As in the case of other groups, deterrent factors are "unfriendly attitude of staff" and "bureaucratized complaint procedure".

The fourth age group includes people of retirement age. As a rule, they have a low income level, which does not give them the opportunity to abandon the use of public transport in favor of personal vehicle. Drawing on their life experience, more than half of surveyed retirees do not count on the solution of the problem that might occur in public transport, nor do they think that the solution will be timely. About 35\% are stopped by the absence of monetary compensation. Interestingly, the level of awareness of the pensioners about the complaint procedure is comparable with the underage group (about 30\% do not know what steps to take in case of a complaint intention). In addition, this group is significantly limited with their complaint intention by technical difficulties (more than 
any other group).

Another pattern can be traced between the income level of citizens and the factors that deter them from filing a complaint (see Figure 3b). People with income level above the regional average are the least affected by such factors as the absence of special technical devices that are required to file a complaint (computer, phone, fax, etc.), alternative means of transportation or provided compensation. Probably the majority of respondents in this group have experience of working with people, since the factors such as "personal beliefs", "features of the mentality" and the "language barrier" are obstacle for only 10.4-14.6\% of respondents. This is almost $1.5-2$ times less than in the other groups. In addition, they are characterized by the highest awareness of the complaint procedure. The main constraints to the complaint intention of the respondents with high income are highly bureaucratic complaint procedure and the lack of faith in the fact that the problem will be solved.

For respondents with an average income of greater importance in comparison with other groups are the factors of unavailable compensation and the need to spend personal time and money. As a rule, despite the emergence of a negative critical incident, many passengers of an average income group cannot renounce the use of public transport. This stops them from engaging in a complaint behavior. Notable, the members of this group are less afraid of a bureaucratized complaint procedure. The percentage of citizens who are repelled by this factor is by $4-10 \%$ less than in the other groups.

The group of respondents with low-income level showed similar dependences as the middle-income group. However, more acute are the social problems associated with the respondent's personal qualities, the ability and/or desire to communicate with others and susceptibility to unfriendly behavior of the interlocutor. Significant impediment to the complaint is the loss of urgency of the problem at the times it will eventually be addressed by the company.

Table 1 presents a summary of the twelve barrier factors ranked in terms of the perceived impact force over the complaint intentions based on gender, age and income level of the respondents.

Table 1. Distribution of barrier factors by influence on different groups of respondents

\begin{tabular}{|c|c|c|c|c|c|c|}
\hline \multirow[b]{2}{*}{ Factors } & \multicolumn{6}{|c|}{ Share of respondents for whom this factor is perceived as a barrier } \\
\hline & $\begin{array}{l}\text { less than } \\
15 \%\end{array}$ & $15-25 \%$ & $25-35 \%$ & $35-45 \%$ & $45-55 \%$ & $\begin{array}{c}\text { more than } \\
55 \%\end{array}$ \\
\hline Unfriendly attitude of staff & & & $\mathrm{b}$ & $\begin{array}{l}\text { F / M; c /d; } \\
\text { HI /AI /LI }\end{array}$ & $\mathrm{a}$ & \\
\hline $\begin{array}{l}\text { Necessity to spend personal } \\
\text { time and / or money }\end{array}$ & & & $\mathrm{a}$ & $\begin{array}{l}\mathrm{M} ; \mathrm{b} / \mathrm{d} \\
\mathrm{HI} / \mathrm{LI}\end{array}$ & $\begin{array}{c}\mathrm{F} ; \mathrm{c} \\
\mathrm{AI}\end{array}$ & \\
\hline $\begin{array}{l}\text { Bureaucratized complaints } \\
\text { procedure }\end{array}$ & & & $\mathrm{a} / \mathrm{b}$ & $\begin{array}{l}\text { F / M; d; } \\
\text { AI / LI }\end{array}$ & $\begin{array}{l}\mathrm{c} ; \\
\mathrm{HI}\end{array}$ & \\
\hline $\begin{array}{l}\text { High probability that the } \\
\text { problem will not be resolved }\end{array}$ & & & $\mathrm{a}$ & $\begin{array}{l}\mathrm{b} ; \\
\mathrm{AI}\end{array}$ & $\begin{array}{c}\text { F /M; c; } \\
\text { HI /LI }\end{array}$ & $\mathrm{d}$ \\
\hline No compensation provided & & $\begin{array}{l}\mathrm{a} / \mathrm{c} ; \\
\mathrm{HI}\end{array}$ & $\begin{array}{l}\text { F /M; b; } \\
\text { AI / LI }\end{array}$ & $\mathrm{d}$ & & \\
\hline Do not know what to do & $\begin{array}{l}\mathrm{c} ; \\
\mathrm{HI}\end{array}$ & $\begin{array}{l}\mathrm{F} / \mathrm{M} \\
\mathrm{AI} / \mathrm{LI}\end{array}$ & $\mathrm{a} / \mathrm{b} / \mathrm{d}$ & & & \\
\hline $\begin{array}{l}\text { Takes too long to get a } \\
\text { response }\end{array}$ & & & $\mathrm{a}$ & $\begin{array}{c}\mathrm{b} ; \\
\mathrm{HI} / \mathrm{AI}\end{array}$ & $\begin{array}{c}\mathrm{F} / \mathrm{M} ; \mathrm{c} / \mathrm{d} \\
\mathrm{LI}\end{array}$ & \\
\hline Language barrier & $\begin{array}{l}\mathrm{c} ; \\
\mathrm{HI}\end{array}$ & $\begin{array}{c}\mathrm{F} / \mathrm{M} ; \mathrm{a} / \mathrm{b} / \mathrm{d} ; \\
\mathrm{AI} / \mathrm{LI}\end{array}$ & & & & \\
\hline Features of the mentality & $\begin{array}{l}\mathrm{a} / \mathrm{c} ; \\
\mathrm{HI}\end{array}$ & $\begin{array}{c}\mathrm{F} / \mathrm{M} ; \mathrm{b} / \mathrm{d} \\
\mathrm{AI} / \mathrm{LI}\end{array}$ & & & & \\
\hline No possibility to abandon the & HI & a & M; & $\mathrm{F}$ & d & \\
\hline
\end{tabular}




\begin{tabular}{|c|c|c|c|}
\hline use of public transport & & & $\mathrm{b} / \mathrm{c}$ \\
\hline Personal beliefs & $\begin{array}{c}\mathrm{F} / \mathrm{M} ; \mathrm{c} \\
\mathrm{HI}\end{array}$ & $\begin{array}{l}\mathrm{a} / \mathrm{b} / \mathrm{d} ; \\
\mathrm{AI} / \mathrm{LI}\end{array}$ & \\
\hline Technical difficulties & $\begin{array}{c}\mathrm{F} / \mathrm{M} ; \mathrm{a} / \mathrm{b} / \mathrm{c} ; \\
\mathrm{HI} / \mathrm{AI} / \mathrm{LI}\end{array}$ & d & \\
\hline
\end{tabular}

Note. color denotes the average value of the share of respondents in each of the factors; $\mathrm{F}$-female; $\mathrm{M}$ - male; $\mathrm{a}-$ underage; $\mathrm{b}$ - young people; $\mathrm{c}$ - working people; $\mathrm{d}$ - retired; HI - high-income; AI - average income; LI low-income.

Table 1 clearly indicates the influence of such personal attributes of a complainant as age, gender and income level in evaluating the barrier factors. While answers of certain types of complainants show greater deviation from the average value, indicating their sensitivity to various aspects, e.g. technical difficulties or knowledge of the complaint procedure.

\section{Conclusion}

Customer feedback is a valuable source of information for transportation companies on the ways to improve the service quality and, consequently, to enhance market competitiveness. Therefore, management of the company should be interested to receive feedback from passengers about the services provided. The complaint is considered as one of the ways to obtain this kind of information. Therefore, we believe that the complaint process should be organized in such a way that the client should meet as few obstructions on his way as possible.

Current research has shown that perceived complaint barriers vary depending on gender, age and income level of the complainant. However, the negative attitude of staff and the need for substantial spending of personal time and money deters most groups of respondents from engaging into a complaint behavior and filing a complaint to the company. This should be considered when designing a system for filing complaints in public passenger transport companies, as well as the subsequent service recovery systems. In addition, we believe that contextual conditions are highly influential in the complaint process. We conducted a study in the field of public transportation in Kaliningrad, because this city is of interest on the one hand as a tourist center and the administrative center of the westernmost region of Russia, located in the heart of Europe, and on the other hand as an average provincial town, of which there are many. Further research on the topic of barriers to customer complaint behavior should test the defined pattern in other contextual environment and industries, as well as consider additional complainant personality traits to be studied.

\section{References}

Anton, J. (1996). Customer relationship management: Making hard decisions with soft numbers. Prentice Hall.

Atalik, O. (2009). Voice of Turkish Customer: Importance of Expectations and Level of Satisfaction at Airport Facilities. Review of European Studies, 1(1), 61-67. http://dx.doi.org/10.5539/res.v1n1p61

Bearden, W. O., \& Mason, J. B. (1984). An Investigation of Influences on Consumer Complaint Reports. In T. Kinnear (Ed.), Advances in Consumer Research (Vol. 2, pp. 490-495). Provo, UT: Association for Consumer Research.

Best, A., \& Andreasen, A. R. (1977). Consumer Response to Unsatisfactory Purchases: A Survey of Perceiving Defeats, Voicing Complaints \& Obtaining Redress. Law and Society Review, 11(4), 701-742. http://dx.doi.org/10.2307/3053179

Bloch, P. H., \& Richins, M. L. (1983). A theoretical model for the study of product importance perceptions. Journal of Marketing, 47(Summer), 69-81. http://dx.doi.org/10.2307/1251198

Blodgett, J. G., Wakefield, K. L., \& Barnes, J. H. (1995). The effects of customer service on consumer complaining behavior. Journal of services Marketing, 9(4), 31-42. http://dx.doi.org/10.1108/08876049510094487

Blodgett, J., Hill, D., \& Tax, S. (1997). The effects of distributive, procedural and interactional justice on $\begin{array}{llll}\text { post-complaint behavior. Journal of Retailing, } & \text { 73(2), }\end{array}$ http://dx.doi.org/10.1016/S0022-4359(97)90003-8

Crosier, K., \& Erdogan, B. Z. (2001). Advertising complainants: Who and where are they? Journal of Marketing Communications, 7(2), 109-120. http://dx.doi.org/10.1080/13527260121943 
Dabholkar, P. A. (1994). Technology-based service delivery. In T. A. Schwartz, D. E. Bowen, \& S. W. Browns (Eds.), Advances in Services Marketing and Management Research and Practice. (pp. 241-271). JAI Press.

Davidow, M., \& Dacin, P. A. (1997), Understanding and influencing consumer complaint behaviour: Improving organisational complaint management. Advances in Consumer Research, 24(1), 450-456.

Day, R. L., \& Ash, S. B. (1979). Consumer response to dissatisfaction with durable products. Advances in Consumer Research, 6, 438-444.

Day, R. L., \& Landon, E. L. (1976). Collecting Comprehensive Consumer Complaint Data By Survey Research. In B. B. Anderson (Ed.). Advances in Consumer Research (Vol. 3, pp. 263-268). Cincinnati Association for Consumer Research.

Day, R. L., \& Landon, E. L. (1977). Toward a Theory of Consumer Complaining Behavior. In A. G., Woodside, J. N. Sheth, \& P. D., Bennett (Eds.), Consumer and Industrial Buying Behavior (pp. 425-437). New York: North-Holland Publishing.

Dunning, J., Pecotich, A., \& O'Cass, A. (2004). What happens when things go wrong? Retail sales explanations and their effects. Psychology \& Marketing, 21(7), 553-572. http://dx.doi.org/10.1002/mar.20019

Duval, D. T. (2007). Tourism and Transport: Modes, Networks and Flow. Clevedon, Buffalo: Channel View Publications.

Fellesson, M., \& Friman, M. (2008). Perceived satisfaction with public transport service in nine european cities. Journal of the Transportation Research Forum, 47(3), 93-104.

Goodwin, C., \& Ross, I. (1992). Consumer responses to service failures: Influence of procedural and interactional fairness perceptions. Journal of Business Research, 25(2), 149-163. http://dx.doi.org/10.1016/0148-2963(92)90014-3

Hoffman, K., Kelly, S. W., \& Rotalsky, H. M. (1995). Tracking service failure and employee recovery efforts. Journal of Services Marketing, 9(2), 49-61. http://dx.doi.org/10.1108/08876049510086017

Keaveney, S. (1995). Customer switching behavior in service industries: An exploratory study. Journal of Marketing, 59(2), 71-82. http://dx.doi.org/10.2307/1252074

Krishnan, S., \& Valle, A. V. (1979). Dissatisfaction attributions and consumer complaint behavior. Advances in Consumer Research, 6, 445-449.

McCollough, M. A., Berry, L. L., \& Yadav, M. S. (2000). An empirical investigation of customer satisfaction after service failure and recovery. Journal of Service Research, 3(2), 121-137. http://dx.doi.org/10.1177/109467050032002

Mikhaylov, A. S., \& Mikhaylova, A. A. (2014). The public transportation of Russia and Sweden: A comparative analysis of service quality from customer perspective. Journal of Applied Economic Sciences, 3(29), 422-432.

Oliver, R. L., \& Swan, J. E. (1989). Equity and disconfirmation perceptions as influences on merchant and product satisfaction. Journal of Consumer Research, 16(December), 372-383. http://dx.doi.org/10.1086/209223

Richins, M. L. (1982). An investigation of consumer attitudes toward complaining. In A. Mitchell (Ed.), Advances in Consumer Research (pp. 502-506). Association for Consumer Research, Provo, UT.

Singh, J. (1989). Determinants of consumers' decisions to seek third party redress: An empirical study of dissatisfied patients. Journal of Consumer Affairs, 329-363. http://dx.doi.org/10.1111/j.1745-6606.1989.tb00251.x

Smith, A. K., Bolton, R. N., \& Wagner, J. (1999). A Model of Customer Satisfaction with Service Encounters Involving Failure and Recovery. Journal of Marketing Research, 36(3), $356-372$. http://dx.doi.org/10.2307/3152082

Stephens, N., \& Gwinner, K. (1998), Why don't some people complain? A cognitive-emotive process model of consumer complaint behavior. Journal of the Academy of Marketing Science, 26(3), 172-189. http://dx.doi.org/10.1177/0092070398263001

Tronvoll, B. (2008). Customer Complaint Behaviour in Service. Doctoral dissertation. Karlstad: Karlstad University Studies. 


\section{Copyrights}

Copyright for this article is retained by the author(s), with first publication rights granted to the journal.

This is an open-access article distributed under the terms and conditions of the Creative Commons Attribution license (http://creativecommons.org/licenses/by/3.0/). 